\title{
Article
}

\section{Strategi Politik Calon Legislatif Muda Partai Perindo Dalam Memenangkan Pemilihan Legislatif Tahun 2019 Kabupaten Merangin}

\author{
Andri Putra Kesmawan ${ }^{1 *}$, dan Age Marja ${ }^{2}$
}

This article is an open access article distributed under the terms and conditions of the Creative Commons Attribution-ShareAlike 4.0 International (CC BY SA ) License (https://creativecommo ns.org/licenses/by$\mathrm{sa} / 4.0 /$ ).

\section{Jurnal Politik dan} Pemerintahan Daerah ISSN 2686-2271

Fakultas Ilmu Sosial dan Ilmu Politik, Universitas Muara Bungo Jl. Diponegoro No. 27, Muara Bungo-Jambi, (0747) 323310

\author{
${ }^{1}$ Universitas Muhammadiyah Yogyakarta, Program Studi Ilmu Pemerintahan, Fakultas \\ Ilmu Sosial dan Ilmu Politik Universitas Muara Bungo \\ 2 Universitas Muhammadiyah Yogyakarta, Program Studi Ilmu Pemerintahan, \\ Fakultas Ilmu Sosial dan Ilmu Politik Universitas Muara Bungo \\ *Correspondence Author: andri.putra@umy.ac.id
}

Abstract: The purpose of the study was to find out how the political strategy of winning the young Perindo Party candidates in the 2019 Legislative election in Merangin Regency. Then to find out what are the determinants of the victory of the Perindo Party's young legislative candidates in the 2019 legislative elections in Merangin Regency. The benefit of the research is that it becomes a reference material for other researchers who want to research political strategy from the point of view of modality theory so that they get legislative seats in the regions. The theoretical review used in this research is Political Strategy Theory and Modality Theory. The modality theory used by Legislative Candidate Hasren Purja Sakti is to look at social capital, political capital, economic capital, symbolic capital and cultural capital. The political strategy used is an Opensif strategy and a Defensive strategy. In this study, the author uses a qualitative approach with a descriptive research design. The technique of collecting is by interview and documentation, while the technique of validating the data used by the researcher is using technical triangulation and structuring data collection sources. The selection of informants was done by purposive sampling technique. Based on the results of the study, it can be explained that the political strategy used by HPS in the 2019 legislative election in Merangin Regency is because the elected candidates for HPS are able to apply modalities as a strategy in the electoral arena so that they gain power in the base and weaken the power of other candidates in the basis of electoral district VI because of the power of modality. elected candidates. With the existence of five candidates from the Perindo Regional Election Party VI, this weakens the four candidates themselves and greatly benefits the elected candidates. It can be concluded from the results of this research that HPS's victory in the Perindo young legislative candidate in the electoral arena in the 2019 legislative election is because it is able to utilize and place the modalities that are owned well so that it becomes the political strength of the elected legislative candidate.

Keywords: Political Strategy, Political Modalities, Legislative Election

Abstrak: Tujuan penelitian adalah untuk mengetahui bagaimana strategi politik kemenangan caleg muda Partai Perindo pada pemilihan Legislatif 2019 di Kabupaten Merangin. Kemudian untuk mengetahui apa saja faktor penentu kemenangan calon legislatif muda Partai Perindo pada pemilihan legislatif 2019 di Kabupaten Merangin. Manfaat penelitian yaitu menjadi bahan acuan bagi peneliti lain yang ngin meneliti strategi politik dari sudut dari sudut pandang teori modalitas sehingga mendapatkan kursi legislatif di daerah. Adapun tnjauan teori yang digunakan dalam penelitian ini adalah Teori Strategi Politik dan Teori Modalitas. Teori Modalitas yang digunakan oleg Calon Legislatif Hasren Purja Sakti adalah dengan melihat modal sosial , modal politik, modal ekonomi, modal simbolik dan modal budaya. Staregi politk yang digunakan yaitu 
strategi Opensif dan strategi Depensif. Dalam penelitian ini penulis menggunakan pendekatan kualitatif dengan desain penelitian deskriptif. Teknik pengumpulan dilakukan dengan wawancara dan dokumentasi, sementara teknik keabsahan data yang digunakan penelti menggunakan triangulasi tekni dan truangulasi sumber pengumpulan data. Pemlihan informan dilakukan dengan teknik purposive sampling. Berdasarka hasl penelitian, maka dapat dijelaskan bahwa strategi politik yang diginakan HPS pada pemilihan legislatif 2019 Kabupaten Merangin adalah karena caleg terpilih HPS mampu menerapkan modalitas sebagai strategi di arena electoral sehngga mendapat kekeuatan dddalam basis dan melemahkan kekuatan caleg lain didalam basis daerah pemilihan VI diarenakan kekuatan modalitas caleg terpilih. Dengan adanya lima caleg dari partai perindo daerah pemjilihan VI sehngga melemahkan ke empat caleg mereka sendiri dan sangat menguntungkan caleg terpilih. Dapayt disimpulkan dari hasil peneliti ini menunjukan bahwa kemenangan caleg muda perindo ini HPS di arena electoralpada pemilihan legslatif 2019 karen mampu memnfaatkan dan menempatkan modalitas yang dimilii dengan baik sehngga menjadi kekuatan politik calon legislatif terpilih.

Kata Kunci: Strategi Politik, Modalitas Politik, Pemilihan Legislatif

\section{Pendahuluan}

Pemilihan umum (Pemilu) adalah suatu proses di mana para pemilih memilih oang-orang untuk mengisi jabatan-jabatan politik tertentu. Jabatan-jabatan politik beraneka ragam mulai dari Presiden, wakil rakyat di berbagai tingkat pemerintah sampai kepala desa. Azas pemilu yang digunakan di Indonesia adalah azas langsung, umum, bebas, rahasia (Luber) serta jujur dan adil (Jurdil). Pemilu pertama di Indonesia terjadi pada tahun 1955 hingga saat ini. Azas-azas tersebut tidak berdiri sendiri karena keberadaannya saling melengkapi, azas Luber harus dilengkapi Jurdil dan sebaliknya (Fatayati, 2017). Fungsi dari Pemilu adalah guna memilih pemimpin dari partai politik yang visi serta misinya sesuai dengan apa yang diharapkan oleh masyarakat, sebagai sebuah sarana untuk membentuk sebuah pemerintahan serta sebagai alat untuk membatasi perilaku atau kebijakan pemerintah agar tidak terjadi kesewenangan oleh pemimpin (Pamungkas, 2009). Pemilu pertama mimilih anggota DPR, DPD, DPRD dan Presiden. Indonesia menggunakan sistem pemilihan yang berbeda-beda tetapi lebih banyak didasarkan pada tercakupnya indikator akuntabilitas (accountability), keterwakilan (representativeness) keadailan (fainess), persamaan hak tiap pemilih (aqulity), lokalitas, relyable serta numerical.

Pemilihan umum legislatif 2019 dengan sistem propesional daftar terbuka telah menyebabkan persaingan yang ketat diantara calon legislatif dalam memperebutkan suara. Guna memenangkan kompetisi di ajang pemilu, para calon legislatif di satu partai politik saling bersaing satu sama lain dengan menerapkan berbagai strategi, taktik, dan metode pemenangan politik yang jitu. Strategi politik adalah strategi yang digunakan untuk mewujudkan cita-cita politik (Schhroder, 2004).

Pemilihan Umum Legislatif (Pileg) yang dilaksanakan di Kabupaten Merangin merupakan bentuk implementasi atau pelaksanaan otonomi daerah dan demokratis, pemindahan tanggung jawab wewenang dan sumber - sumber daya dari pemerintah pusat ke level pemerintah daerah untuk membawa pengaruh terhadap politik. Para calon legislatif (Caleg) pun membentuk tim sukses dan melakukan segala cara dan strategi guna untuk memperoleh dukungan dan kemenangan. Pada pemilhan umum Legislatif Kbupaten Merangin Merangin 35 orang caleg terpilih di Kabupaten Merangin, resmi dilantik menjadi anggota dewan 
periode 2019-2024, Jumat (30/8/2019) siang. Dari 35 orang yang dilantik, ada satu orang yang tampak agak berbeda. Wajahnya yang masih muda seperti anak kuliahan, fostur tubuhnya juga tak sama dengan dewan-dewan lainnya. Dia adalah Hasren Purja Sakti. Hasren Purja Sakti, yang berusia 28 tahun saat ini, merupakan anggota dewan termuda yang duduk diperiode ini. Pria kelahiran Desa Pulau Tengah, Koto Jayo, Kecamatan Jangkat, Kabupaten Merangin ini, tidak menyangka dipilih rakyat, sehingga bisa mewakili rakyat diparlemen. Berikut perbandingan usia Caleg Terpilih Kabupaten merangin 2019.

Tabel 1.1 Nama-Nama Calon Legislatif Terpilih dan Perbandingan Usia

\begin{tabular}{l|l|l|l} 
NO & NAMA & PARTAI & UMUR \\
1 & NASIHIN & PKB & 33 TAHUN \\
2 & SYAFRUDDIN CAN & GERINDARA & 36 TAHUN \\
3 & SRI AMIN & PDIP & 37 TAHUN \\
4 & MULYADI, SH & GOLKAR & 35 TAHUN \\
5 & HASAN JALIL & GOLKAR & 50 TAHUN \\
6 & MUHAMMAD YANI, Amd & NASDEM & 40 TAHUN \\
7 & ZAINAL AMRI & PKS & 55 TAHUN \\
8 & ASY SYAHRUL, SE & PR'ERINDO & 39 TAHUN \\
9 & AHMAD KAUSARI, ST.,MT & PAN & 43 TAHUN \\
10 & M. YUZAN, S.Pd & HANURA & 48 TAHUN \\
11 & SAUT TUA AMOSIR & DEMOKRAT & 45 TAHUN \\
12 & NASWAN & GERIDRA & 50 TAHUN \\
13 & H. ZAIDAN, S.Hi & PDIP & 50 TAHUN \\
14 & SAMDIANTO, S.Sos & GOLKAR & 40 TAHUN \\
15 & HERMAN EFENDI, & GOLKAR & 41 TAHUN \\
& S.T., MM & & \\
16 & SUBADRI & NASDEM & 46 TAHUN \\
17 & THALIB & BERKARYA & 54 TAHUN \\
18 & HARYANTO & PKS & 50 TAHUN \\
19 & SUKADI & PERINDO & 42 TAHUN \\
20 & SUBHAN, SE & PPP & 46 TAHUN \\
21 & RAHMAT HIDAYAT & PALKAR & 57 TAHUN \\
22 & AS'ARI EL WAKAS, SH & DEN & 30 TAHUN \\
23 & ABDUL KHALIM, SH & PEMOKRAT & 43 TAHUN \\
24 & DARMADI & 46 TAHUN \\
25 & SUKAR & PDIP & 42 TAHUN \\
26 & MUHAMMAD HELMI, S.Kom & NASDEM & 36 TAHUN \\
27 & SOLIHIN & PKS & 34 TAHUN \\
28 & SYAPARUDIN & PPP & 36 TAHUN \\
29 & TAUFIK, SE & PAN & 37 TAHUN \\
30 & ZAINURI & HANURA & 48 TAHUN \\
31 & SAFRIYON, SH., MH & GERINDRA & 54 TAHUN \\
32 & EDI KHAIRUL FAHMI S.Pd & PDIP & 40 TAHUN \\
33 & SUARDI, S.Pd & HASREN PURJA SAKTI & \\
35 & M. THAIS, S.Pd & TAHUN
\end{tabular}

Sumber: KPU Kabupaten Merangin, diolaholeh penulis 
Dari tabel di atas terlihat jelas perbedaan umur diantara 35 caleg terpilih pada pemilihan legislatif 2019. Hasren Purja Sakti yang berusia 28 tahun merupakan anggota dewan termuda Kabapubaten Merangin 2019 periode 20192024. Hasren Purja Sakti merupakan calon legislatif dari Partai PERINDO untuk daerah pemilihan IV yang meraih suara terbanyak. Perolehan suara Hasren Purja Sakti lebih tinggi dibandingkan dengan perolehan suara calon legislatif Partai PERINDO lainnya. Hal ini dapat dilihat pada tabel berikut:

Tabel 1.2 Nama-Nama Calon Legislatif Partai Perindo dan Perolehan Suara Pada Pemilihan Legislatif 2019 Kabupaten Merangin Daerah Pemilihan IV

\begin{tabular}{l|l} 
No & NAMA CALON LEGISLATIF \\
1 & HASREN PURJA SAKTI \\
2 & GUNTUR AMIR PUTRA \\
3 & YENI AFRITA \\
4 & ZAINUDIN \\
5 & EVI HERLINA
\end{tabular}

PEROLEHAN SUARA
932 Suara
914 Suara
13 Suara
575 Suara
8 Suara

Sumber: KPU Kabupaten Merangin, diolah oleh penulis

Dari tabel diatas terlihat bahwa perolehan suara yang di raih Hasren Purja Sakti adalah 932 suara, mendapatkan suara terbanyak diantara calon legislatif Partai Perindo lainnya terkhusus Daerah Pemilihan IV. Banyak hal yang harus dilakukan untuk bersaing untuk melawan calon legislatif lain dan dari partai politik lain, dan banyak cara yang dilakukan untuk mendapatkan simpati pemilih. Agar dapat memperoleh suara terbanyak, maka perlu strategi politik untuk meraih suara mayoritas masyarakat. Untuk dapat menetapkan pilihan yang tepat, kita harus memiliki kemampuan untuk mengenali pola dasar strategi yang diperlukan. Setelah pola dasar strategi dibangun ada satu pilihan dari sederatan strategi dimana pemilihan ini dipengaruhi oleh syrat-syrat kerangka kerja serta saran-saran organisasi secara umum. Dalam Pemilihan Legislatif Kabupaten Merangin 2019 Daerah Pemilihan IV akan menempati 5 kursi legislatif, dapat di lihat pada tabel berikut:

Tabel: 1.3 Jumlah Suara Partai dan Suara Calon Legislatif Terpilih Kabupaten Merangin Daerah Pemilihan IV

\begin{tabular}{l|l|l|l|l} 
No & Nama Caleg & Nama Partai & Suara Partai & Suara Caleg \\
1 & Suardi & Golkar & 5.599 & 1.944 \\
2 & Edi Khairul Fahmi & PDIP & 5.396 & 2.643 \\
2 & Sapriyon & Gerindra & 3.598 & 2.061 \\
4 & Hasren Purja Sakti & Perindo & 2.553 & 932 \\
5 & M. Tais & Demokrat & 2.490 & 1.102
\end{tabular}

Sumber KPU Kabupaten Merangin, diolah oleh penulis

Dari tabel di atas dapat diketahui bahwa pada Pemilhan Umum Legilatif Kabupaten Merangin Tahun 2019 Hasren Purja Sakti dapat Menduduki kursi ke empat dari lima kursi Daerah Pemilihan IV, kemudian ditetapkan sebagai anggota legislatif terpilih dengan perolehan 932 suara. Begitu pentingnya penerapan strategi sehingga setiap calon legislatif mau tidak mau harus mampu bersaing 
menyusun sebuah strategi politik yang mampu memberikan kemenangan. Tanpa strategi, kekuasan yang merupakan tujuan utama berpolitik tidak akan pernah terwujud. Salah satu kontestan pada pemilu legislatif 2019 adalah Partai Persatuan Indonesia (Perindo) merupakan partai baru yang didirikan oleh Hary Tanoesoedibjo dan di deklarasikan 7 Februari 2015 di Jakarta International Expo. Penggunaan sistem propesional terbuka dengan suara terbanyak pada pemilihan legislatif 2019 telah memberikan kontribusi besar terhadap perolehan suara partai. Calon legislatif yang hanya pasif dan selalu tergantung pada partai politik tentu tidak akan pernah bisa mendapatkan suara untuk mengantarnya mendapatkan kursi. Oleh sebab itu, peran calon legislatif sebagai aktor utama dalam peningkatan suara partai menjadi begitu dominan. Pemilihan umum legislatif Kabupaten Merangin 2019 Daerah Pmilihan IV, terdiri dari lima kecamatan, dan diikuti 36.168 Daftar Pemilih Tetap (DPT). Dapat di lihat pada tabel berikut:

\section{Tabel 1.4 Jumlah Daftar Pemilih Tetap (DPT) per-Kecamatan Dapil IV}

\begin{tabular}{l|l|l} 
No & Nama Kecamatan & Jumlah DPT \\
1 & Tiang Pumpung & 3.681 \\
2 & Muara Siau & 7.470 \\
3 & Lembah Masurai & 10.239 \\
4 & Jangkat & 7.752 \\
6 & Jangkat Timur & 7.026 \\
\multicolumn{1}{|c|}{ Jumlah } & $\mathbf{3 6 . 1 6 8}$
\end{tabular}

Sumber KPU Kabupaten Merangin, diolah oleh penulis

Dari tabel di atas terlihat jelas perbedaan Jumlah Daftar PemilihTetap (DPT) masing-masing Kecamatan Daerah Pemilihan IV. Strategi politik digunakan untuk menciptakan kekuasaan yang di inginkan para politisi untuk merebut kekuasaan di dewan parlemen. Strategi politik bisa digunakan pada masa kampanye untuk memperoleh suara dan dukungan dari masyarakat, sehingga masyarakat dapat terpengaruh dengan strategi yang digunakan para calon legislatif. Para calon legislatif mendekati masyarakat secara lansung dan tidak lansung seperti datang kerumah, mengikuti kegiatan-kegiatan masyarakat, serta berkunjung ke desa-desa. Disini penulis melakukan penelitin terhadap caleg muda dari Partai Perindo yaitu HASREN PURJA SAKTI yang bertujuan untuk mengetahui bagaimana strategi dan faktor penentu kemenangan pada pemilihan legislatif 2019 Kabaupaten Merangin Daerah Pemilihan IV. Calon Legislatif merupakan calon pemimpin harus mampu menawarkan dirinya sebagai pribadi yang baik, dapat dipercaya, dan mampu memberikan kesejahteraan pada pemilihnya sesuai tujuan bangsa dan negara. Untuk melakukan itu, tentu dibutuhkan strategi yang baik bagi Calon legislatif agar bisa menyampaikan gagasan, visi misi, dan program kerja nya jika terpilih sebagai anggota legislatif.

Kenyataan ini telah menimbulkan pertanyaan yang memerlukan jawaban, kiranya strategi apa yang digunakan oleh caleg muda Partai Perindo Dapil VI pada pemilu legislatif 2019 di Kabupaten Merangin. Selanjutnya, untuk keperluan telaah dalam penelitian ini, digunakan teori tentang marketing politik.Studi tentang marketing politik sesungguhnya sudah sejak lama dilakukan, namun sebagai cabang ilmu, marketing politik memang bisa dikatakan masih bayi, tetapi kehadirannya telah menjadi trend dalam ranah politik di negara maju yang menganut demokrasi (Firmanzah, 2007).

Sementara makna dari partai politik itu sendiri adalah proses pembentukan dan pembagian kekuasaan dalam masyarakat yang antara lain berwujud proses pembuatan keeputusan, khususnya dalam negara. Selain itu politik adalah seni dan ilmu untuk meraih kekuasaan secara konstitusional maupun non konstitusional 
(Sugino, 2013). Kandidat dari partai politik berlomba untuk memanfaatkan ilmu ini sebagai strategi kampanye baik untuk memobilisasi pemilih, mendapatkan dukungan politik dalam pemilihan umum maupun untuk memelihara citra sepanjang jeda pemilu. Sebagai kajian keilmuan, marketing politik terus mengalami perkembangan definisi yang beragam dan berubah memberikan penekanan pada proses transaksi yang terjadi antara pemilih dan kandidat. Menekankan penggunaan marketing-mix untuk mempromosikan partai-partai politik. Lock \& Harris mengusulkan agar political marketing memperhatikan proses positioning.

Dengan terpilihnya caleg muda partai perindo ini atas nama Hasren Purja Sakti atau disingkat HPS. Tentu membuat gairah masyarakat merangin terkhusus dapil VI karna mampu mendapatkan pemimpin yang muda dan terutama masyarakat basis calon legislatif muda ini Kecamatan Jangkat khususnya. Indikasi awal jenis strategi politik yang di gunakan pemenang calon legislatif muda ini dalam pemilihan legislatif 2019 di Kabupaten Merangin, strategi yang digunakan strategi opensip dan lebih tepatnya strategi memperluas pasar, ia membentuk tim sukses dan membuat posko pemenangan masing-masing kecamatan di daerah pemilihan IV.

Disinilah letak menariknya. Peneliti ini, di arahkan untuk mampu menjelaskan bagaimana strategi dan memetakan kekuatan, kelemahan, peluang dan hambatan dari strategi yang di terapkan oleh calon legislatif muda Partai Perindo.

Setiap calon legislatif sama-sama memiliki kekuatan dengan berbagai strategi. Kemudian dengan alasan menariknya peneliti melakukan penelitian terhadap calon legislatif muda partai perindo ini adalah dimana caleg terpilih ini dengan umur yang masih muda juga pendatang baru pada pemilhan legislatif Kabupaten Merangin juga pertama kali mencalonkan sebagai anggota legislatif 2019 dan mampu menduduki kursi ke empat dari dari daerah pemilihan VI.

Kemudian calon legislatif muda partai perindo dapil IV ini atas nama HASREN PURJA SAKTI yang berusia 26 tahun dan juga pendatang baru pada pemilihan legislatif, kalau dilihat dari keseharian beliau masyarakat ekonomi menengah kebawah dan juga telah bergabung sebagai kader partai semenjak tahun 2015. Kemudian dia juga sebagai mantan jurnalis dan pernah bergabung di media lokal Merangin, dan menariknya lagi pernah menjadi marketing di sebuah perusahaan. Dalam penetapan nomor urut calon legislatif, calon legislatif dengan usia 26 tahun ini berhasil mendapatkan nomor urut 01 partai Perindo Daerah Pemilihan IV. Berdasarkan fenomena diatas peneliti tertarik untuk melakukan penelitian tentang "STRATEGI POLITIK CALON LEGISLATIF MUDA PARTAI PERINDO DALAM MEMENANGKAN PEMILIHAN LEGISLATIF TAHUN 2019 KABUPATEN MERANGIN" (Studi Kasus Calon Legislatif Hasren Purja Sakti Daerah Pemilihan IV).

\section{Pembahasan}

\section{Strategi Politik Pemenangan Calon Legislatif Muda Partai Perindo Pada Pemilih Legislatif Kabupaten Merangin 2019}

Pada bagian bab ini, peneliti akan memfokuskan untuk membahas secara rinci strategi politik yang di gunakan oleh "HASREN PURJA SAKTI" di Pemilihan Legislatif 2019 Kabupaten Merangin untuk memperoleh suara dan dukungan dari masyarakat pemilih. Penggunaan strategi yang tepat merupakan salah satu hal yang paling penting yang dilakukan oleh HPS dalam menarik simpati masyarakat untuk dapat menjadi pemenang pada pemilihan legslatif, hal itu tidaklah mudah tentu butuh usaha, upaya dan tindakan oleh setiap calon yang ikut dalam pemilihan legislatif. Penggunaan strategi yang tepat pada akhirnya akan mengerucut pada penerapan berbagai taktik yang lebih detail dan konkrit yang akan di 
implementasikan di lapangan. Berikut ini strategi politik yang di gunakan "HPS" Untuk bertarung di pemilihan legslatif 2019 Kabupaten Merangin yaitu:

\section{a. Strategi Ofensip}

Strategi opensif selalu di perlukan jka partai ingin meningkatkan jumlah pemilihnya, atau seorang calon yang ngin mengaplikasikan sebuah program. Dalam kedua kasus tersebut kampanye dapat berhasil hanya jka ada lebih banyak orang yang memiliki pandangan positif terhadap partai atau program program yang di tawarkan tersebut. Yang termasuk strategi opensif adalah strategi memperluas pasar dan strategi menembus pasar semua strategi opensif yang di terapkan saat kampanye harus mmenampilkan perbedaan yang jelas dan menarik antara dengan partai yang lain. Strategi opensip yang digunakan untuk menerapkan subuah kebijakan harus menjual atau menampilkan perbedaan terhadap status atau keadaan yang berlaku saat itu.

Strategi ofensif diterapkan pada saat kampanye politik. Strategi kampanye suatu proses yang dirancang secara sadar, bertahap dan berkelanjutan yang dilaksanakan pada rentang waktu tertentu dengan tujuan mempengaruhi sasaran yang telah ditetapkan. Pada dasarnya strategi kampanye politik bertujuan untuk membentuk serangkaian makna politis tertentu didalam pikiran parapemilih. Serangkaian makna politis yang terbentuk dalam pikiran para pemilih tersebut dimaksudkan untuk memilih kontestan tertentu. Makna politis inilah yang menjadi out put penting dari strategi kampanye politik.

Strategi kampanye politik yang adalah perbedaan terhadap keadaan yang harus dijual atau seperti ini perlu dipersiapkan bagi kandidat sebagai sebuah strategi kampanye pengantar untu menjelaskan kepada publik tentang penawaran mana saja yang lebih baik,dibandingkan dengan penawaran calon-calon lainnya dan memanfaatkan situasi dan kondisi yang terjadi dalam masyarakat. Misalnya hal-hal yang menjadi kebutuhan masyarakat dalam mensejahterahkan hidupnya, dapat menjadi kunci untuk merumuskan strategi ini. Menurut penulis, karakteristik utama strategi ofensif ini yang berorientasi pada pemilih/pasar, setidaknya ada beberapa hal, diantaranya mempunyai komitmen yang kuat, mempunyai kapabilitas yang berbeda apabila dibandingkan dengan calon yang lain, mampu mempertemukan kapasilitas yang dimiliki calon dengan apa yang menjadi nilai bagi pemilih dan selalu berusaha dan mampu menggerakkan semua komponen yang ada.

Hal inilah yang dilakukan HPS dan tim pemenangan pada saat kampanye dilakukan. HPS dan tim pemenangan melalukan sosialisasi dan memperkenalkan HPS sebagai Calon Legislatif. Melalui proses sosialisasi politik inilah masyarakat memperoleh sikap dan orientasi terhadap kehidupan politik yang berlangsung dalam masyarakat, untuk itu perlu yang dilakukan demi mendapatkan target (perolehan suara yang diinginkan).

\section{b. Strategi Defensif}

Strategi defensip akan muncul ke permukaan jka partai atau sebuah koalisi yang terdiri atas beberapa partai ingin mempertahankan mayoritasnya atau jika pasar ingin di pertahankan. Selain itu starategi defensif juga dapat muncul apabla sebuah pasar tidak dipertahankan lebh lanjut atau ngin ditutup, dan penutupan ini agar dapat membawa perubahan atau keuntungan besar. Strategi Defensif digunakan apabila para caleg ingin mempertahankan mayoritasnya atau apabila perolehan suara yang dicapai sebelumnya ingin strategis, dinamis, berdimensi jangka panjang dan jangka 
pendek yang mana dipraktikkan oleh partai politik untuk menyebarkan makna politik ke pemilih dengan dipertahankan. Strategi ini dibangun oleh caleg sebagai salah satu cara untuk memelihara dukungan suara.

Pemilihan Lesgislatif tahun 2019, seluruh calon legislatif adu kekuatan atau yang biasa disebut adu strategi. Tentu dalam kompetisi politik seluruh calon ingin menjadi pemenang, namun masyarakat masing-masing punya kriteria untuk jadi wakil rakyatnya. Pada pemilihan legislatif diperlukan strategi yang merupakan hal utama dalam menghadapi kompetisi politik. Strategi tersebut tentu bertujuan untuk simpatik masyarakat dan memperoleh suara sebanyak-banyaknya pada pemilihan legislatif 2014 . tujuan membentuk dan menanamkan sikap, harapan, keyakinan, orientasi dan perilaku pemilih. Seorang caleg harus mampu menyusun sebuah strategi bagai cara mempertahankan suara keluarga atau basis agar tdak memilih caleg lain dan mampu menawarkan kesan menarik terhadap pemilih masyarakat khususnya agar bsa mendapatkan dukungan dan hak suara mereka. Modalitas yang Dipakai dalam arena elektoral di saat ini, sebagai strategi politik bagi calon yang bertarung dalam pemilihan legislatif kabupaten merangn. terlihat dalam berbaga bentuk basis yang di unggulkan yang merupakan kekuatan utama yang tidak dapat dihindarkan oleh sang calon yang bertarung, termasuk Hasren Purja Sakti yang bertarung di arena elektoral untuk memenangkan sebuah pertarungan politik. Hal ini dikarenakan peran modalitas sebaga langkah awal bagi terbentuknya strategi politk yang tepat bagi Hasren Purja Sakti untuk bertarung di arena elektoral.

1. Modal Sosial

Melihat modal sosial latar belakang yang di miliki calon legislatif HPS bisa di cermati yaitu: pendidkan, pekerjaan awal, ketokohan dalam masyarakat ( tokoh Agama, adat, organisasi kepemudaan dan lain sebagainya) pada uumnya terkait pada keunggulan-keunggulan yang dimiliki calon berupa, dukungan pigur atau ketokohan (popularitas) yang dapat di cermati dari peran sosial yang dilakukan serta relasi yang terbangun diantara sang calon dengan masyarakat (voter) karena saling kepercayaan (trust) ada beberapa indikator dari modal sosal (social capital): ketokohan (popularitas), Relasi kepercayaan (trust) yang di bangun masyarakat, pengalaman politik dan pengalaman organisasi dan memliki kapasitas secara intelektual. Secara ketokohan sudah dikenal halayak itu terbukti dengan pendidikan, pekerjaan, ketokohan dalam organisasi kepemudaa. Ini menandakan bahwa modal sosial (social capital) yang dimiliki sangat besar tidak semua calon memiliki modal sosial seperti HPS dilihat dari segi pekerjaan sudah beda dengan calon perindo dapil IV lainya.

2. Modal Politik

Setiap calon harus mampu menempatkan sebuah kesan diri yang positif dalam kalangan masyarakat pendukungnya. HPS menempatkan kesan diri yang postitif yang ada di kalangan masyarakat pendukungnya dan partai pendukung. Adanya partai pendukung pencalonan Hasaren Purja Sakti pada pemilihan legislatif 2019 Kabupaten Merangin guna untuk menyatukan visi misi dari partai politik. Oleh karena itu, di bentuknya tim sukses pemenangan Hasren Purja Sakti adalah upaya-upaya yang dilakukan oleh partai politik yang telah 
menyatukan sebuah tujuan dalam memenangkan pemilihan legislatif 2019.

Partai juga akan memberikan sebuah kemudahan akses dan kebersamaan untuk semakin intens memperkokoh konsepkonsep yang telah disepakat bersama. Dari 453 calon yang mengikuti konstasi di pemlihan legislatif 2019 Kabupaten Merangin. Hasren Purja Sakti yang di dukung oleh partai politik yaitu Partai Persatuan Indonesa (PERNDO).

Partai tersebut di atas mengusung dan mencalonkan Hasren Purja Sakti sehingga memudahkan jaringan pemenangan yang di miliki oleh parta pendukung khususnya membangun sebuah jaringan dan kekuatan politik yang sangat besar buat HPS. Hal ini menjadi sebuah keunggulan baik dari segi psikologis maupun kekuatan riil politik dari sang calon ini. Jaringan- jaringan politik ini bekerja secara maksimal untuk memenangkan calon yang diusung dan didukungnya. Modalitas politik di dukung oleh partai Perindo basis daerah pemilihan empat yaitu: Kecamatan Tiang Pumpung, Kecamatan Muara Siau, Kecamatan Lembah Masurai, Kecamatan Jangkat dan Kecamatan Jangkat Timur Kabupaten Merangin tentunya. Strategi politik yang digunakan oleh HPS sudah senada dengan yang di ungkapkan oleh Sun Tzu dan di tulis oleh Peter Schoder yang merumuskan strategi, menjelaskan bahwa dalam pemilihan strategi harus ada hal-hal tertentu yang di perioritaskan karena strategi politik untuk mewujudkan citacita politik (kemenangan). Sun Tzu: bentuk terbaik pemimpin perang adalah menyerang strategi lawan, terbaik ke dua adalah menghancurkan aliansi lawan dan yang terbaik berikutnya adalah menyerang tentara lawan, yang terburuk adalah menduduki kota-kota di benteng lawan (Miranti, 2015). Artinya apa yang dilakukan HPS di pemilihan Legislatif Kabupaten Merangin tentang strategi politik adalah menyerang strategi lawan dan menghancurkan aliansi lawan walaupun belum bisa memenangi semua wilayah dapil empat Kabupaten Merangin, strategi politik yang digunakan adalah srategi opensip itu terlebih dari apa yang dilakukan oleh HPS.

\section{Modal Ekonomi}

Sistem pemilihan legislatif yang digunakan sistem suara terbanyak yaitu dengan melakaukan pemilihan secara lansung, mengharuskan setiap calon harus mempunyai harta yang melimpah sebega ongkos politik (political fee). Nyaris dukungan pinanasial ini tidak bisa dihindarkan lagi bagi setiap calon. Pada saat HPS melakaukan kampanye politik HPS mendapat donatur dana dari Abadion Sutra selaku toke hasil bumi kecamatan jangkat sebanyak 115 juta. Untuk membantu ongkos politk HPS Pada saat pemilihan legislatif Kabupaten Merangin 2019. Oleh karena itu, bagi orang yang tidak memiliki kekayaan melimpah, maka kemungkinan besar tidak bisa mengikuti kontestasi pemelihan legislatif. Biaya politik yang begitu mahal ini, bisa menjadi hambatan bagi siapapun yang mempunyai kredibilitas dan layak mencalonkan diri di pemilihan legislatif Kabupaten Merangin karana tidak mempunyai biaya politik. Maka dengan sistem sepert ini, para 
pengusaha sukses adalah orang yang ideal mengikuti kontestasi pemilhan umum. Tak heran fase perpolitikan di Indonesia kini di kuasai oleh pengusaha. Tapi disisi lain HPS sangat lemah dalam modal ekonomi. Modal ekonomi sangat berperan aktif dalam kemenangan HPS, yaitu di dukung oleh toke dan keluarga yang ada di pedesaan, fungsi modal ekonomi dignakan untuk modal politik dan untuk komunikasi politik, kampanye politik dan sebaganya. Sebelumnya bahwa HPS didukung oleh modal ekomomi yang cukup besar tetapi tidak di publikasi sehingga cuma menjadi issu saja. Artinya kesadaran masyarakat tidak lepas dari eksistensi masyarakat dan perorangan ditentukan oleh kondisi-kondisi materi dan basis inilah yang mendertiminasi terbentuknya basis soaial, politik maupun kultur.

4. Modal simbolik dan modal budaya

Kata simbol berasal dari kata Yunani, symbolos yang berati tanda atau ciri yang memberitahukan suatu hal kepada seseorang. Dalam kamus ilmiah populer smbolik adalah perlambangan. Gaya bahasa yang melukiskan suatu benda dengan mempergunakan benda-benda lain sebagai simbol atau pelambang. Pada saat Hasren Purja Sakti mencalonkan diri untuk memngikuti pemilihan anggota legislatif, Hasren Purja Sakti kelihatan dekat dengan Al Haris Selaku Bupati Merangin. Salah satu yang mempengaruh kemenangan HPS dengan adanya kedekatan dengan Al Haris selaku Bupat Kabupaten Mrerangin ., sangat berpengaruh positif terhadap majunya sebagai calon anggota legslatif yaitu dengan cara mendekatkan diri dengan petinggi Kabupaten Merangin. Kedekatan HPS dengan Bapak Al Haris dibuktkan dengan kerja sama yang kuat membentuk sebuah lembaga di kabupaten merangin yaitu sebuah lebaga Pemuda Pancasila. Artinya modal sosial yang berupa hubungan-hubungan sosial yang memungkinkan seseorang bermobilisasi demi kepentingannya sendri itu dilakuakan oleh Hasren Purja Sakti.

Strategi politik Hasren Purja Sakti melihat bahwa perbedaan asal tanah kelahiran sangatlah dominan, kemudian mendapat keuntungan tersendiri dari para pemilih tradisional artinya di dukung oleh masyarakat pedesaan yang mengutamakan putra daerah dan sebagainya. Hasren Purja Sakti mempunyai dukungan politik yang dilakukan oleh para pemilih tradisional maupun masyarakat pada umumnya di arena elektoral. HPS mempunyai modal politik, karena memiliki basis-basis pemilih tradisional dan masyarakat tradisional yang loyal terhadap HPS. Memiliki wilayah adat masing daerah, memilik kedekatan dengan pemodal yang ada di pedesaan sehingga di bantu dalam pinansial pertemuan dan kamppanye. Kenmudian juga memiliki tokoh agama, tokoh masyarakat dan pemuda. Dari analisis peneliti di atas bahwa modalitasi sosial dan modalitas politik yang sangat dominan, sementara modaliitas ekonomi HPS tidak menentukan sebuah keberhasilan. 


\section{Faktor penentu kemenangan Hasren Purja Sakti pada pemlilihan legislatif Kabupaten Merangin 2019}

\section{a. Faktor Eksternal}

Secara eksternal, HPS memilik banyak peluang yaitu dengan adanya dukungan partai pengusung dan parata pendukung yang cukup besar, Tm sukses, Elektabilitas Partai, Popularitas Prtai, Popularitas, Akseptabilitas, Elektabilitas kandidat, kesan dan pandangan yang baik terhadap figur, ketetapan sosal, Tokoh Masyarakat, Adat dan Kepemudaan, persepsi masyarakat terhadap semangat perubahan yang baik.

Namun juga memiliki hambatan yang tidak kecil diantaranya alah kandidat lain, tim skses kandidat lain, kemungkinan pemlih mengubah pemilhannya, kecurangan, politik uang, massa mengambang, pemilih lemah, knerja tim sukses, penggunaan pasilitas negara, netraltas penyelenggara pemilu, netralitas media. Kondisi eksternal ini, harus mampu dimanfaatkan dan harus bsa diatasi dengan kekuatan yang dimiliki kandidat. Kemenangan kemenangan suatu caleg tdak bisa lepas dari dukungan partai, tim sukses, dan kelompok organisasi lain.

b. Faktor Internal

Secara internal, HPS memilik kekuatan dan kelemahan untuk kekuatan cenderung masalah kepribadiannya yang menonjol. Kekuatan yang dmiliki HPS yaitu dukungan penuh dari keluarga, dukungan penuh dari nenek mamak orang tuo tau cerdik pandai sanak saudara, berpengalaman di pemerintahan dan birokrasi, tokoh muda dan putra daerah Kabupaten Merangin. Kelemahan HPS yaitu pendatang baru di kancah politik Kabupaten Merangin, Strategi ini harus mampu mengubah sekecl apapun peluang dengan kekuatan internal yang dimiliki. Hal-hal yang perlu di perhatikan dalam strategi ini ialah frekuens tatap muka dengan masyarakat angat perlu ditingkatkat agar bisa meyakinkan masyarakat terutama di kalangan keluarga, tatap muka media sosialisai sangat efektif, menekan partai pengusung untuk terud bekerja sosialisasi ke masyarakat, fokus bersosislisasi mengenalkan calon, mengenalkan program yang dampak positif secara lansung terhadap masyarakat, tekan dan pantau semaksimal mungkin permainan politik uang.

Strategi kandidat mampu menggunakan kekuatan untuk mengatas hambatan yaitu pertahankan zona basism massa, pertahan hak pilih keluarga besar, serang zona lawan untuk untuk mengubah kemungkinan pilihan, manfaatkan data survey menentukan zona pilihan mengambang dan pemlih lemah, dokumentasikan kecurangan pihak lawan memantau tim sukses sendiri, hindari penggunaaan pasiltas Negara dalam bersosalisasi maupun kampanye, memonitor dan evaluasi kerja tim, berikan penghargaan bagi tim berknerja baik, berikan teguran bagi tim berkinerja buruk, awasi berkepihakan ASN dan penyelenggara pemilu. Selain itu HPS perlu mengenalkan diri ke masyarakat dan apa alasan mencalonkan diri. Peluang yang telah tercipta wajb di ketahui dan segera dimanfaatkan untuk mengubah pilihan dan mempertahankan dukungan. Lakukan hubungan kekeluargaan yang erat dengan koalisi partai pengusung dan tim pemenang, manfaatkan tokoh partai pengusung untuk perbaiki citra negatifdan isu miring, batas dengan ketat ruang gerak nkeluarga di birokrasi, tanggapi lansung tentang isu negatif menggunakan media atau tatap muka lansung, manfaatkan hubungan baik calon dengan ormas, fokus sosislisasi mengenalkan calon.

Kelemahan yang ada harus diatasi untuk mengurangin hambatan seperti libatkan tokoh masyarakat, tokoh adat, ulama pemuda dan menbangun hubungan keluarga dan memperbaiki citra lemah di masyaraka, tokoh lokal setempat diperhatakn, pembiayaan opersional pemenang lebih jelas, dan 
mudah cair, perbaki penctraan negatif, kerahkan segenapmormas untuk menaikkan elektabilitas, kampanyekan prestas yang dimiliki HPS, fokus sosialisasi mengenalkan calon, atasi keluarga yang berpotensi menyalahgunakan kewenangan. Penetapan strategi merupakan langkah krusial yang memerlukan penanganan secara hati-hati dalam bertindak dak berkampanye sebab jika penerapan strategi salah satu keliru, maka hasil yang diperoleh bisa fatal, terutama kerugian dari segi waktu, materi dan tenaga. Maka salah satu faktor penentu kemenangan-kemenangan Hasren Purja Sakti. Strategi politik sebenarnya harus matang agar kelemahan-kelemahannya bisa diatasi oleh HPS dan tim sukses pemenangan.

\section{Penutup}

Kesimpulan dari penelitian ini adalah strategi Hasren Purja Sakti dalam memperoleh suara dan dukungan pada pemilihan legislatif Kabupaten Merangin tahun 2010 yang dilakukan di dapil IV yang meliputi Kecamatan Tiang Pumpung, Kecamatan Muara Siau, Kecamatan Lembah Masurai, Kecamatan Jangkat dan Kecamatan Jangkat Timur Strategi Defensif dan Strategi Opensif. Dengan perolehan suara 932 mengantarkan Hasren Purja Sakti pada kemenangan pemilihan legislatif tahun 2019 Kabupaten Merangin. Strategi serta pemasaran politik yang disusun Hasren Purja Sakti beserta Tim Sukses yang merupakan orang-orang yang sangat dekat dengan Hasren Purja Sakti berhasil merebut dan mendapatkan simpati masyarakat pada pemilihan legislatif tahun 2019 Kabupaten Merangin.

Saran yang hendak disampaikan adalah 1) Harus adanya edukasi politik sebagai strategi politik yang bertujuan untuk memberikan pendidikan atau pandangan politik yang bermartabat dan bermanfaat untuk masyarakat. 2) Untuk mempromosikan diri calon legislatif harus aktif di kegiatan sosial, kegiatan pemuda, Karang Taruna, kemasyarakatan sehingga masyarakat simpati dan mendukungnya baik dalam masa kampanye maupun tidak.

\section{Referensi}

Bourdieu, Pieere. (1991). Language and Symbolic Power, Cambridge-UK, Polity Press.

Fatayati, S. (2017). Relevansi Asas-Asas Pemilu Sebagai Upaya Menciptakan Pemilu Yang Demokratis Dan Berintegritas. Jurnal Relevansi, 28.

Firmanzah, M. P. (2007). Antara Pemahaman dan Realitas. Jakarta: Yayasan Obor Indonesia. Labolo, M\& Ilham,Teguh. (2014). Partai politik dan sistem pemilihan umum di Indonesia, Jakarta.

Miranti. (2015). Perempuan dan Poilitik Local. Gre Publishing.

Pamungkas, S. (2009). Perihal Pemilu, Yogyakarta. Laboratorium Jurusan Ilmu Pemerintahan dan Jurusan Ilmu Pemerintahan.

Schhroder, P. (2004). Strategi Politik. Feiedrich Naumann Stiftun.

Sugino, A. (2013). Strategic Political Marketing. Ombak. 